\title{
ANALISIS AGROINDUSTRI GULA AREN DI KECAMATAN RAMBAH SAMO KABUPATEN ROKAN HULU
}

\author{
Muhammad Tarmizi \\ Jurusan Agribisnis, Fakultas Pertanian, Universitas Riau \\ Email: tarmizimuhammad0@gmail.com
}

\begin{abstract}
Agroindustry is an integrated system involving agricultural, human, science and technology resources, money and information. Agroindustry products can be either ready-to-eat products or other industrial raw materials. This study aims to analyze the sugar palm agroindustry in District Rambah Samo Rokan Hulu District. The method used is survey method, sampling is done by using census method as many as 18 craftsmen in District Rambah Samo. The analysis used is quantitative descriptive analysis. The results of this study indicate that sugar palm agroindustry in District Rambah Samo Rokan Hulu regency still use traditional tools for generations that are old enough. Palm sugar processing is divided into 2 stages of cooking and packing where in terms of the cost of craftsmen earned an average of Rp.900.661 with $R / C$ ratio 1.25 can be said that sugar palm agroindustry profit and feasible to run and developed.
\end{abstract}

Keywords: palm, sugar, agroindustry, cost

\begin{abstract}
Abstrak : Agroindustri merupakan suatu sistem terintegrasi yang melibatkan sumberdaya hasil pertanian, manusia, ilmu dan teknologi, uang dan informasi. Produk Agroindustri dapat berupa produk akhir yang siap dikonsumsi ataupun sebagai produk bahan baku industri lainnya. Penelitian ini bertujuan untuk menganalisis agroindustri gula aren di Kecamatan Rambah Samo Kabupaten Rokan Hulu. Metode yang digunakan adalah metode survei, pengambilan sampel dilakukan dengan menggunakan metode sensus sebanyak 18 pengrajin yang ada di Kecamatan Rambah Samo. Analisis yang digunakan adalah analisis deskriptif kuantitatif. Hasil penelitian ini menunjukkan bahwa agroindustri gula aren di Kecamatan Rambah Samo Kabupaten Rokan Hulu masih menggunakan alat tradisional secara turun temurun yang usianya sudah cukup tua. Pengolahan gula aren terbagi menjadi 2 tahap pemasakan dan pengemasan dimana dari segi biaya pengrajin mendapat untung ratarata Rp.900.661 dengan $R / C$ ratio 1,25 dapat dikatakan bahwa agroindustri gula aren untung dan layak untuk dijalankan dan dikembangkan.
\end{abstract}

Kata kunci: aren, gula, agroindustri, biaya

\section{PENDAHULUAN}

Sektor pertanian merupakan sektor yang diprioritaskan pembangunannya guna mendorong pembangunan perekonomian Indonesia. Konsep agribisnis adalah suatu konsep yang utuh, mulai dari produksi, mengolah hasil, pemasaran dan aktivitas lain yang berkaitan dengan kegiatan pertanian (Soekartawi, 2010). Potensi agribisnis tersebut akan diikuti dengan perolehan manfaat lain, diantaranya adalah semakin terbukanya kesempatan mobilitas sumberdaya, terutama modal dan tenaga kerja dari sektor pertanian kesektor lain, seperti industri dan jasa, dan sebaliknya. Hal ini akan menempatkan kedudukan kegiatan pertanian yang semakin penting dalam perekonomian nasional, tanpa harus membuat sektor lain menjadi berkurang artinya.

Agribisnis dapat diterapkan pada semua komoditi dalam usahatani dibidang pertanian 
salah satunya adalah komoditi aren yang ada di Kecamatan Rambah Samo Kabupaten Rokan Hulu. Agroindustri sebagai salah satu subsistem penting dalam sistem agribisnis yang memiliki potensi untuk mendorong pertumbuhan ekonomi yang tinggi karena pangsa pasar dan nilai tambah yang relatif besar dalam produk nasional. Selanjutnya agroindustri juga dapat mempercepat transformasi disektor perekonomian dan pertanian ke industri. Sebagai penggerak pembangunan pertanian, agroindustri diharapkan dapat memainkan peranan penting kegiatan pembangunan daerah dalam sasaran pemerataan pembangunan ekonomi. Keberadaaan agroindustri di pedesaan diharapkan dapat meningkatkan permintaan terhadap komoditas pertanian, karena sektor agroindustri berperan dalam mengubah produk pertanian menjadi barang yang lebih berguna bagi kebutuhan masyarakat dan dapat meningkatkan pendapatan masyarakat.

Kecamatan Rambah Samo sebagai sentra produksi gula aren di Kabupaten Rokan Hulu yang dikenal sebagai penghasil gula aren tradisional yang diolah dari nira pohon aren (Arenga pinnata merr) yang diusahakan secara turun temurun dan kualitasnya juga sudah terjamin. Adapun tujuan dari penelitian ini adalah menganalisis agroindustri gula aren di Kecamatan Rambah Samo Kabupaten Rokan Hulu.

\section{METODE PENELITIAN}

Penelitian ini dilakukan di Kecamatan Rambah Samo di Kabupaten Rokan Hulu, Pemilihan lokasi ini dilakukan secara sengaja (purposive), dengan pertimbangan bahwa Kecamatan Rambah Samo merupakan salah satu kecamatan sentra produksi aren di Kabupaten Rokan Hulu. Penelitian ini dilaksanakan mulai bulan November 2016.

Metode yang digunakan dalam penelitian adalah metode survey. Penarikan sampel petani/pengrajin dilakukan dengan cara sensus. Untuk menganalis agroindustri dapat dilakukan menggunakan analisis deskriptif kuantitatif.

Untuk menganalisis pendapatan yang diperoleh pengrajin gula aren menggunakan rumus (Suratiyah, 2015):

$$
\begin{array}{ll}
\mathrm{TR} & =\mathrm{Py} . \mathrm{Y} \\
\mathrm{TC} & =\mathrm{FC}+\mathrm{VC} \\
\pi & =\mathrm{TR}-\mathrm{TC} \\
& =(\mathrm{Py} . \mathrm{Y})-(\mathrm{FC}+\mathrm{VC}) \\
\mathrm{a} & =\mathrm{TR} / \mathrm{TC}
\end{array}
$$

Keterangan:

$$
\begin{array}{ll}
\pi & =\text { Pendapatan Bersih }(\mathrm{Rp}) \\
\mathrm{TR} & =\text { Pendapatan Kotor }(\mathrm{Rp}) \\
\mathrm{TC} & =\text { Biaya Total }(\mathrm{Rp}) \\
\mathrm{Py} & =\text { Harga Produksi }(\mathrm{Rp} / \mathrm{liter}) \\
\mathrm{Y} & =\text { Jumlah Produksi (liter) } \\
\mathrm{FC} & =\text { Biaya Tetap (Fixed Cost })(\mathrm{Rp}) \\
\mathrm{VC} & =\text { Biaya Tidak Tetap (Variable } \\
& \text { Cost) }(\mathrm{Rp}) \\
\mathrm{a} & =\text { R/C ratio }
\end{array}
$$

Apabila nilai $\mathrm{R}>\mathrm{TC}$ maka pengrajin gula aren memperoleh keuntungan, apabila nilai $\mathrm{R}=\mathrm{TC}$ maka pengrajin gula aren tidak untung dan tidak rugi, dan apabila nilai $\mathrm{R}<\mathrm{TC}$ maka pengrajin gula aren mengalami kerugian.

\section{HASIL DAN PEMBAHASAN}

Agroindustri gula aren di Kecamatan Rambah Samo adalah usaha yang menjadi salah satu sumber pendapatan bagi masyarakat. Agroindustri gula aren ini sudah dilakukan secara turun temurun dengan memanfaatkan nira aren dari pohon aren yang tumbuh di lahan masyarakat yang ada di Kecamatan Rambah Samo. Namun bahan baku nira yang tersedia sudah semakin berkurang karena penyadapan yang dilakukan secara terus menerus, sehingga pohon aren tidak bisa lagi memproduksi air nira setelah berproduksi lebih kurang 10 tahun. .

Menurut Sa'id dan Intan (2004), manajemen produksi dalam usaha pengolahan hasil pertanian (agroindustri) juga memerlukan penanganan yang lebih serius karena sangat tergantung pada ketersediaan masukan, terutama bahan baku, dan juga ketersediaan pasar. Pelaksanaan proses produksi dalam agroindustri didasarkan pada rencana produksi yang telah dibuat. Pada tahap ini input-input yang telah direncanakan dan disediakan dimasukkan keproses produksi sesuai jadwal, jumlah, dan jenis, serta urutan yang telah direncanakan untuk menghasilkan output produksi. 
Muhammad Tarmizi : Analisis Agroindustri Gula Aren...

Tabel 1. Bahan Baku dan Bahan Penunjang Dalam Pengolahan Gula Aren

\begin{tabular}{clcccc}
\hline No & \multicolumn{1}{c}{ Bahan } & Harga (Rp) & Rata-rata Jumlah (Bln) & Rata-rata Biaya/ bulan (Rp) & Persentase (\%) \\
\hline 1 & Nira Aren (Liter) & 3 & 498 & 1.492 .941 & 97,50 \\
2 & Daun Pisang (Ikat) & 1 & 10,18 & 10.863 & 0,71 \\
3 & Kayu Bakar (Ikat) & 3 & 7,86 & 21.529 & 1,41 \\
4 & Korek Api (Bungkus) & 1 & 4 & 3.941 & 0,26 \\
5 & Raru & 5 & 0,35 & 1.912 & 0,13 \\
\hline \multicolumn{2}{c}{ Jumlah } & & 1.531 .186 & 100 \\
\hline
\end{tabular}

Tabel 2. Biaya Upah Tenaga Kerja di Kecamatan Rambah Samo Kabupaten Rokan Hulu Perbulan

\begin{tabular}{cccc}
\hline No & Kegiatan & Jam kerja/hari & Upah TK/bulan(Rp) \\
\hline 1 & Penyadapan & 0,10 & 29.12 \\
2 & Pemasakan & 3,08 & 833.958 \\
3 & Pengemasan & 0,16 & 43.68 \\
\hline & Jumlah & 3,34 & 906.758 \\
\hline
\end{tabular}

Hasil penelitian menunjukkan bahwa 97,50\% pengeluaran untuk bahan baku nira aren dengan biaya Rp.1.492.941/bulan. Bahan penunjang seperti, daun pisang, kayu bakar, korek api dan raru merupakan bahan yang digunakan sebagai bahan penunjang yang dibutuhkan dalam pengolahan gula aren. Beban biaya terbesar ditunjukkan dengan persentase terbesar yaitu bahan kayu bakar yang menjadi bahan penunjang yang penting dalam proses pemasakan dengan biaya Rp.21.529/bulan sedangkan pada raru dengan biaya terkecil Rp.1.912/Bulan. Rata-rata biaya perbulan yang dikeluarkan pengrajin dalam mengolah gula aren senilai Rp.1.531.186.

Pada Tabel 2 menunjukkan bahwa ratarata upah tenaga kerja perbulan Rp.906.658 dengan jumlah jam kerja selama 3,34 jam. Upah tenaga kerja terbesar ditunjukkan pada kegiatan pemasakan Rp.833.958/bulan dengan jumlah jam kerja rata-rata 3,08 jam/hari. Tenaga kerja yang digunakan rata-rata pengrajin pada pengolahan gula aren adalah tenaga kerja dalam keluarga (TKDK). Hal ini dikarenakan agroindustri gula aren juga merupakan usaha utama dan usaha sampingan bagi pengrajin.

Menurut Soekartawi (2001), biaya produksi adalah nilai dari semua faktor produksi yang digunakan, baik dalam bentuk benda maupun jasa selama proses produksi berlangsung. Adanya unsur-unsur produksi yang bersifat tetap dan tidak tetap dalam jangka pendek mengakibatkan munculnya dua kategori biaya, yaitu biaya tetap dan biaya variabel.

Biaya pengolahan gula aren adalah semua biaya yang dikeluarkan oleh pengrajin baik biaya tetap maupun biaya tidak tetap. Menurut Suratiyah (2015) biaya tetap merupakan biaya yang besarnya tidak dipengaruhi besarnya produksi dan biaya variabel yaitu biaya yang besarnya dipengaruhi oleh besarnya produksi.

Adapun biaya tetap yang dimiliki oleh pengrajin usaha gula aren terdiri dari : upah tenaga kerja dan biaya penyusutan alat yang digunakan dalam pengolahan gula aren. Biaya tidak tetap yang dibutuhkan untuk satu bulan produksi adalah biaya bahan baku dan bahan penunjang.

Tabel 3. Rata-rata Biaya Tetap dan Tidak Tetap Pengolahan Gula Aren di Kecamatan Rambah Samo Perbulan

\begin{tabular}{rlr}
\hline No & \multicolumn{1}{c}{ Uraian } & Biaya/bulan (Rp) \\
\hline 1 & Biaya Tetap & 913.173 \\
& -Penyusutan Alat Penyadapan & 2.172 \\
& -Penyusutan Alat Pengolahan & 4.243 \\
& -Upah Tenaga Kerja (Dalam Keluarga) & 906.758 \\
2 & Biaya Tidak Tetap & 1.531 .186 \\
& -Bahan pengolahan & 1.531 .186 \\
\hline
\end{tabular}

Berdasarkan Tabel 3, rata-rata pengrajin yang mengolah gula aren mengeluarkan biaya tetap sebesar Rp.913.173/ bulan Biaya tetap yang dikeluarkan pengrajin meliputi biaya penyusutan alat dan upah tenaga kerja dalam keluarga. Biaya terbesar yang dikeluarkan adalah upah tenaga kerja dalam keluarga sebesar Rp 906.758. Besarnya biaya tetap upah tenaga kerja disebabkan rata-rata upah petani perhari di Kabupaten Rokan Hulu dihargai 
cukup besar senilai Rp.100.000/hari. Biaya tidak tetap merupakan biaya bahan pengolahan sebesar Rp.1.531.186/bulan. Biaya tidak tetap meliputi bahan baku (nira aren), dan bahan penunjang (daun pisang, kayu bakar, korek api dan raru).

Jumlah keseluruhan biaya yang dikeluarkan oleh pengrajin gula di Kabupaten Rokan Hulu adalah hasil penjumlahan antara biaya tetap dengan biaya tidak tetap. Total biaya merupakan keseluruhan biaya yang dikeluarkan dalam proses produksi sampai terciptanya barang, dimana total biaya tersebut adalah biaya pengolahan gula aren. Tingginya biaya yang dikeluarkan pengrajin tergantung banyaknya alat, tenaga kerja dan bahan yang digunakan. Secara umum, produksi dapat diartikan sebagai kegiatan optimalisasi dari faktor-faktor produksi seperti, tenaga kerja, modal, dan lain-lainnya oleh pengrajin untuk menghasilkan produk berupa barang-barang dan jasa-jasa.

Pendapatan pengrajin terbagi menjadi dua yakni, pendapatan kotor dan pendapatan bersih. Pendapatan kotor adalah semua penerimaan atau produksi dikali dengan harga jual. Pendapatan bersih adalah seluruh pendapatan kotor yang diperoleh oleh petani yang telah dikurangi biaya tetap dan biaya tidak tetap (Suratiyah, 2015). Untuk mengetahui besarnya penerimaan yang diperoleh pengrajin gula aren di Kecamatan Rambah Samo yaitu dengan cara mengalikan jumlah gula aren yang diproduksi dengan harga gula aren pada waktu itu.

Tabel 4.Rata-Rata Produksi Gula Aren, Harga Jual, Pendapatan Kotor, Total Biaya dan Pendapatan Bersih Gula Aren di Kecamatan Rambah Samo

\begin{tabular}{rlr}
\hline No & \multicolumn{1}{c}{ Uraian } & Rata-rata/Bulan (Rp) \\
\hline 1 & Produksi (Kg) & 167 \\
2 & Harga Jual & 20 \\
3 & Pendapatan Kotor & 3.345 .020 \\
4 & Biaya Produksi & 2.444 .359 \\
5 & Pendapatan Bersih & 900.661 \\
\hline
\end{tabular}

Berdasarkan Tabel 4 rata-rata produksi sebanyak $167 \mathrm{Kg} /$ bulan, dan dapat dikatakan produksi cukup besar, mengingat rata-rata pengrajin melakukan pengolahan gula aren setiap hari. Harga jual gula aren sebesar Rp.20.000/Kg, atau sama dengan 2 bungkus/Kg nya.Rata-rata total biaya produksi yang dikeluarkan pengrajin Rp.2.444.359/bulan, sehingga rata-rata pendapatan kotor yang diterima pengrajin sebesar Rp.3.345.020/bulan, dan rata-rata pendapatan bersih pengrajin sebesar Rp.900.661/bulan. Agroindustri gula aren merupakan usaha yang sudah terbukti menguntungkan pengrajin namun mengingat kendala yang dialami pengrajin seperti terbatasnya bahan baku yang ada sehingga menyebabkan terbatasnya pengrajin gula aren memproduksi setiap hari. Hasil penelitisn Shafira et all (2015), Produksi gula aren yang diperoleh pengrajin selama periode produksi (1 bulan) adalah rata-rata sebesar 207,24 kg per usaha per bulan, dimana harga yang berlaku pada saat penelitian Rp 14.000 per kg, maka penerimaan dari hasil pengolahan gula aren rata-rata sebesar Rp 2.901.360 per usaha per bulan.

Analisis return cost ratio adalah analisis untuk melihat perbandingan (ratio atau nisbah) antara penerimaan (revenue) dengan biaya (cost). Analisis return cost ratio digunakan untuk melihat apakah pengolahan gula aren yang dilakukan pengrajin untung, rugi, ataupun impas.

Tabel 5. Rata-Rata R/C ratio Pengolahan Gula Aren di Kecamatan Rambah Samo

\begin{tabular}{clr}
\hline \multirow{2}{*}{ No } & \multicolumn{1}{c}{ Uraian } & \multicolumn{2}{c}{ Rata-rata/ } \\
& & Bulan (Rp) \\
\hline 1 & Biaya Tetap & 913.713 \\
& -Penyusutan Alat Penyadapan & 2.172 \\
& -Penyusutan Alat Pengolahan & 4.243 \\
& -Upah Tenaga Kerja & 906.758 \\
2 & Biaya Tidak Tetap & 1.531 .186 \\
& -Bahan Pengolahan & 1.531 .186 \\
3 & Produksi (Kg) & 167 \\
4 & Harga Jual & 20 \\
5 & Total Biaya & 2.444 .359 \\
6 & Pendapatan Kotor & 3.345 .020 \\
7 & Pendapatan Bersih & 900.661 \\
8 & R/C ratio & 1,25 \\
\hline
\end{tabular}

Biaya tetap perbulan didapat dari jumlah dari biaya penyusutan alat dan upah tenaga kerja dalam keluarga yang berjumlah Rp.913.713/bulan. Biaya tidak tetap hasil dari 
biaya bahan pengolahan selama satu bulan sebesar Rp.1.531.186 sehingga total biaya dari biaya tetap dengan biaya tidak tetap sebesar Rp.2.444.359/bulan. Produksi yang dihasilkan pengrajin selama sebulan sejumlah $167 \mathrm{Kg}$ dengan harga per $\mathrm{Kg}$ Rp.20.000. rata-rata pendapatan kotor pengrajin sebesar Rp.3.345.020/bulan, dan pendapatan bersih didapat sejumlah Rp.900.661/bulan, sehingga nilai $R / C$ ratio sebesar $1,25 . R / C>1$, dapat dikatakan bahwa usaha agroindustri gula aren menguntungkan, yang diartikan bahwa pengrajin mendapatkan untung dan dapat disimpulkan juga bahwa usaha gula aren layak untuk dijalankan, bahkan sangat menguntungkan jika akan dikembangkan. Berbeda dengan hasil penelitian Pareallak et al (2017), pendapatan bersih rata-rata pengrajin gula aren di Desa Peridan dan Desa Kandolo Kabupaten Kutai Timur besar dari Rp 2.500.000 perbulannya. Pendapatan pengrajin didaerah ini jauh lebih besar dari pendapatan pengrajin gula aren yang ada di Kecamatan Rambah Samo. Begitu juga hasil penelitian Wagiono et all (2014), pada usaha pengolahan gula merah kelapa selama periode produksi (1 bulan) di Desa Medono rata-rata total penerimaan yang diperoleh pengrajin gula merah kelapa adalah sebesar Rp. 803.763,50 perusaha per bulan dan rata-rata total biaya yang dikeluarkan oleh pengrajin gula merah kelapa adalah sebesar Rp. 347.665,54 per usaha per bulan sedangkan rata-rata pendapatan yang diperoleh pengrajin gula merah kelapa di Desa Medono adalah sebesar Rp. 456.097,96 per usaha per bulan.

\section{KESIMPULAN DAN SARAN}

Agroindustri gula aren di Kecamatan Rambah Samo Kabupaten Rokan Hulu masih menggunakan alat pengolahan tradisional turun temurun yang usianya sudah cukup tua dan penggunaan tenaga kerja dalam keluarga. Dalam pengolahan gula aren terbagi menjadi 2 tahap pemasakan dan pengemasan dimana dari segi biaya pengrajin mendapatkan pendapatan bersih sebesar Rp.900.661 dengan $R / C$ ratio 1,25 dapat dikatakan bahwa agroindustri gula aren untung dan layak untuk dijalankan dan dikembangkan. Selain itu agroindustri gula aren disarankan dapat dilakukan dengan menggunakan cara yang lebih modern dengan memperbarui alat yang digunakan agar lebih efisien dalam pengolahan gula aren.

\section{DAFTAR PUSTAKA}

Mugiono, Marwanti, S, Awami, S.Analisis Pendapatan Usaha Gula Merah Kelapa (Studi Kasus Di Desa Medono Kecamatan Kaliwiro Kabupaten Wonosobo). Jurnal Ilmu Pertanian $\begin{array}{llll}\text { Volume } & 10 & \text { No.2 } & 2014 .\end{array}$ http:www.publikasi.unwahas.ac.id/indek s.php. Diakses 15 Agustus 2017.

Pareallak, Marni, Suhadi, I, Ramlah. 2017. Analisis Pendapatan Agroindustri Gula Aren di Kabupaten Kutai Timur (Studi kasus di desa Peridan dan desa Kandolo). Jurnal Pertanian Terpadu. http: ojs.stiperkutim.ac.id/index.php/jpt. Diakses tanggal 20 Juli 2017.

Shafira, K, Fauzia, L, Iskandarini. 2015. Analisis Kelayakan Usaha Gula Aren (Studi Kasus Desa Mancang Kecamatan Selesai Kabupaten Langkat.Jurnal on Social Economic of Agriculture and Agribusiness Volume 4 No 92015. https://jurnal.usu.ac.id/index.php/ceress/a rticle/view/14410. Diakses tanggal 23 Agustus 2017.

Said, G dan A.H. Intan, 2004 Manajemen Agribisnis, . PT. Ghalia Indonesia. Jakarta.

Soekartawi. 2001.Analisis Usahatani. UI Press. Jakarta

Soekartawi. 2010. Agribisnis Teori dan Aplikasi. Rajawali Press. Jakarta.

Suratiyah, Ken, 2015. Ilmu Usahatani. Penebar Swadaya Jakarta. 